\title{
Spectrophotometric Assessment of the Differences Between Total Nitrate/Nitrite Contents in Peel and Flesh of Cucumbers
}

\author{
Anna Stachniuk $^{1}$ (D) - Agnieszka Szmagara ${ }^{2}$ - Elżbieta Anna Stefaniak ${ }^{2}$
}

Received: 11 December 2017 / Accepted: 23 April 2018 / Published online: 7 May 2018

(C) The Author(s) 2018

\begin{abstract}
A spectrophotometric method based on the reduction of nitrates to nitrites was applied to the determination of the difference between total nitrate and nitrite contents in the extracts from the cucumber peel and flesh. The content of these ions was determined in glasshouse cucumbers and those grown in the open fields, both marketed in Poland. Nitrate and nitrite extraction was performed using the Griess diazotization reaction and carried out according to the ISO recommendation (ISO 6635, 1984). It was observed that the mean nitrate content in the peel was significantly higher $(p<0.0001)$ than the mean nitrate content in the flesh. It was also proved that cucumber peel accumulated nearly threefold higher amount of nitrates than the flesh. The nitrite concentrations in all tested samples were below the limit of quantification. Despite statistically significant differences in the nitrate contents between the peel and the flesh, no excessive levels were found. A comparison of the current results to those reported for Poland and other countries is also presented.
\end{abstract}

Keywords Nitrate $\cdot$ Nitrite $\cdot$ Spectrophotometry $\cdot$ Cucumber $\cdot$ Peel

\section{Introduction}

Cucumber (Cucumis sativus L.) is one of the most agriculturally valuable vegetable species of the Cucurbitaceae. It is cultivated by humans with historical records dating back 5000 years (Eifediyi and Remison 2010). The cucumber crop is the second most important vegetable crop after tomato in Western Europe and the fourth most important vegetable crop after tomato, cabbage and onion in Asia (Eifediyi and Remison 2010). According to FAOSTAT (www.faostat.fao. org) statistics for 2012, Poland was the first in the European Union for the area planted with cucumber and the second for production (Kozik 2016). An annual consumption of cucumbers in Poland is about $6.24 \mathrm{~kg}$ per capita (Korzeniewska et al. 2016). Cucumber contains various bioactive compounds, such

Anna Stachniuk

lianna@kul.pl

1 Laboratory of Separation and Spectroscopic Method Applications, Center for Interdisciplinary Research, The John Paul II Catholic University of Lublin, ul. Konstantynow 1J, 20-708 Lublin, Poland

2 Laboratory of Composite and Biomimetic Materials, Center for Interdisciplinary Research, The John Paul II Catholic University of Lublin, ul. Konstantynow 1J, 20-708 Lublin, Poland as polyphenols, carotenoids, several important vitamins, and minerals. A significant part of them is located in cucumber peel which constitutes about $10-15 \%$ of a fresh fruit weight (Mansfeld and Grumet 2016, Guler et al. 2013). Despite the nutritional benefit, cucumbers may also contain substances that adversely affect human health such as pesticides (Leili et al. 2016), mycotoxins (Sahar et al. 2009), heavy metals (Mansour et al. 2009), or nitrates and nitrites (Bahadoran et al. 2016, Razei et al. 2014, Chung et al. 2011, Temme et al. 2011).

Nitrates and nitrites are widely recognized as ions naturally present in the environment. They are abundant in plant foods as a part of a nitrogen cycle. Nitrates in the soil are a primary source of nitrogen, essential for plant growth. Many papers report that nitrate concentrations in vegetables depend on a number of factors, including biological properties of a plant culture, light intensity, type of soil, temperature, humidity, frequency of plants in the field, plant maturity, vegetation period, harvesting time, storage time, and fertilization (Vahed et al. 2015; Costagliola et al. 2014; Tamme et al. 2006). Among them, fertilization and light intensity have been identified as the factors that have the most important impact on a nitrate content in vegetables (Gruda 2005). As reported by Tamme et al., vegetables grown in heated greenhouses have higher nitrate contents than those grown in the open air during the same season, mainly due to lower light intensity and high nitrogen mineralization (Tamme et al. 2010). 
Vegetables are the main source of nitrates in human daily diets and represent about $85 \%$ of nitrates consumed daily (Sušin et al. 2006). Although nitrates are not harmful, they may be reduced in saliva and a gastrointestinal tract to become more toxic nitrites which can react with amines or amides to form carcinogenic, mutagenic, and teratogenic N-nitroso compounds (Gorenjak and Cencič 2013, Menard et al. 2008). High nitrate dietary intake has been found to be associated with gastric cancer (Rezaei et al. 2014). The best known ill effect of nitrites is methemoglobinemia in infants (Vahed et al. 2015). Many systems in infant bodies (nervous, reproductive, digestive, respiratory, and immune) are in developing phase which makes them more sensitive to xenobiotics. Hemoglobin of infants is more susceptible to form methemoglobin and an activity of methemoglobin reductase, an enzyme responsible for reduction of methemoglobin to hemoglobin is low (Rebelo et al. 2015; Vasco and Alvito 2011). In order to protect human health, the European Commission has established maximum levels for certain contaminants in food (EC 2006a). The maximum level of nitrates is defined for two leafy vegetables: spinach (2000-3500 mg kg-1) and lettuce (2000-4500 mg kg-1) and for processed cereal-based foods and baby foods for infants and young children (200 mg kg${ }^{-1}$ ). The European Commission Scientific Committee on Food (SCF) recommended an acceptable daily intake (ADI) of maximum $3.7 \mathrm{mg}$ for nitrates and $0.06 \mathrm{mg}$ for nitrites per $1 \mathrm{~kg}$ of a body weight (Opinion 2008). In the case of infants, their dietary exposure to nitrates tends to be higher than consumed by adults when the ingested amount is calculated with respect to a body weight.

On the other hand, recent studies suggest that nitrates may also be beneficial for human health (Bahadoran et al. 2016; Cortesi et al. 2015; Gorenjak and Cencič 2013; Santamaria 2006). It is based on a hypothesis that nitric oxide formed in a stomach from dietary nitrates has antimicrobial effects on gut pathogens which prevents microbial infection and affords gastric protection (Gorenjak and Cencič 2013, Santamaria 2006).

Several analytical procedures have been developed for the determination of nitrates and nitrites in vegetables, including cucumbers. Over the years, several approaches have been proposed, such as spectrophotometry (Bahadoran et al. 2016; Rezaei et al. 2014; Raczuk et al. 2014; Gajewska et al. 2009), spectrofluorimetry (Wang et al. 2016; Shariati-Rad et al. 2015), potentiometry (Tamme et al. 2006), photometry (Sušin et al. 2006), ion chromatography (Czajkowska et al. 2014; Chung et al. 2011; Menard et al. 2008), and gas chromatography (Tietze et al. 2007) as well as high-performance liquid chromatography (Temme et al. 2011; Tamme et al. 2010). Among them, the spectrophotometric methodology based on the reduction of nitrates to nitrites is traditionally used to determine their content in vegetables (International Standard ISO 6635).

Studies about screening a wide range of vegetables (including cucumbers) have been presented in several papers. Previous studies showed that the main attention was paid to various aspects of nitrate and nitrite presence in vegetables, including general monitoring (Kmecl et al. 2017; Sušin et al. 2006), seasonal variations (Chung et al. 2011; Gajewska et al. 2009), a difference between domestic and imported cucumbers (Tamme et al. 2010), nitrogen fertilization and a nitrogen content in soils (Razgallah et al. 2016), growth in greenhouses (Tamme et al. 2010), various cooking methods which may affect a nitrate level (Vahed et al. 2015; Chung et al. 2011), and an assessment of a dietary risk (Menard et al. 2008). Moreover, various studies have shown that the distribution of nitrates and nitrates is not uniform across different parts of a plant (Vahed et al. 2015, Chung et al. 2011). Higher levels of nitrates tend to be located in leaves whereas they occur at lower concentrations in seeds and tubers (Ekart et al. 2013; Tamme et al. 2010). In the present study, our attention was focused on a distribution of nitrites and nitrates between cucumber peel and flesh as this vegetable is consumed both unpeeled and peeled. We applied a spectrophotometric method to verify if there are any differences between the nitrate and nitrite content in the extracts obtained separately from cucumber peel and flesh. The cucumber fruits chosen for the study were grown both in glasshouses and in open fields, and then purchased in local markets in Lublin (Poland).

\section{Experimental}

\section{Reagents and Samples}

All of the chemical materials used in this study were of analytical grade. Ultrapure water of $18.2 \mathrm{M} \Omega$ resistivity was obtained from a Millipore Direct Q 3UV water purification system and was used for preparing all the reagents and standard solutions and for sample extraction. All reagents and standards including sodium nitrite, sodium nitrate, cadmium sulfate octahydrate, hydrochloric acid, sodium tetraborate decahydrate, Carrez reagent I (potassium hexacyanoferrate II trihydrate) and Carrez reagent II (zinc acetate dihydrate), glacial acetic acid, ammonia hydroxide $25 \%$, and Griess reagent I (sulphanilamide) and Griess reagent II (N-(1-naphthyl)-ethyl-enediamine dihydrochloride) were purchased from Merck (Warsaw, Poland) and were prepared strictly according to International Standard ISO (6635: 1984). Zinc in rods was obtained from Fluka (Poznan, Poland), and a paper filter (no. 40), both nitrate- and nitrite-free was acquired from Whatman (Germany). All cucumbers (1 kg of each type) were purchased in local markets in Lublin during the summer season. A 50\% of analyzed cucumbers were grown in greenhouses. They were kept fresh. Soil and other impurities were removed from them by quick rinsing with water and drained with a paper towel. Just before the analysis, the samples were peeled, cut into small pieces, and homogenized in a Braun MR $6550 \mathrm{M}$ blender, separately peel and flesh. Recovery experiments were carried out using the samples spiked with a nitrate or nitrite standard solution. 


\section{Extraction}

Nitrate and nitrite extraction was performed using the Griess diazotization reaction and carried out according to the ISO method (ISO 6635: 1984). The Griess reagent was used for measuring nitrites and in the case of nitrate levels, a previous reduction of nitrate to nitrite was conducted. The scheme of the extraction procedure is shown in Fig. 1. Briefly, $10 \mathrm{~g}$ of a homogenized sample was measured and transferred to a $250 \mathrm{ml}$ conical flask. Then, $100 \mathrm{ml}$ of hot ultrapure water $\left(70-80{ }^{\circ} \mathrm{C}\right.$ ) and $5 \mathrm{ml}$ of the borax solution were added. The mixture was heated for $15 \mathrm{~min}$ in a water bath $\left( \pm 100{ }^{\circ} \mathrm{C}\right)$. Clarification was done by adding $2 \mathrm{ml}$ of Carrez I and $2 \mathrm{ml}$ of Carrez II. After cooling to a room temperature, the sample was transferred to a $200 \mathrm{ml}$ volumetric flask and then filtered through a Whatman No. 41 filter paper. In order to measure a nitrite content of the sample, Griess reagent I, hydrochloric acid, and Griess reagent II were added to the extract. The solution was incubated in the dark and the absorbance was measured at $538 \mathrm{~nm}$. In order to measure a total nitrate concentration in the sample, the reduction of nitrates to nitrites was accomplished using the cadmium solution. After reduction, the sample was filtered into a $50 \mathrm{ml}$ volumetric flask and then Griess reagent I, hydrochloric acid, and Griess reagent II were added. The absorbance was measured at $538 \mathrm{~nm}$. The blank was processed in the same manner as the real sample, but replacing the studied material with $10 \mathrm{ml}$ of ultrapure water. For the validation, the samples were spiked with appropriate volumes of the standard nitrate and nitrite solutions before extraction.
Fig. 1 Schematic diagram of sample preparation for determination of nitrates and nitrites in cucumbers according to ISO 6635:1984

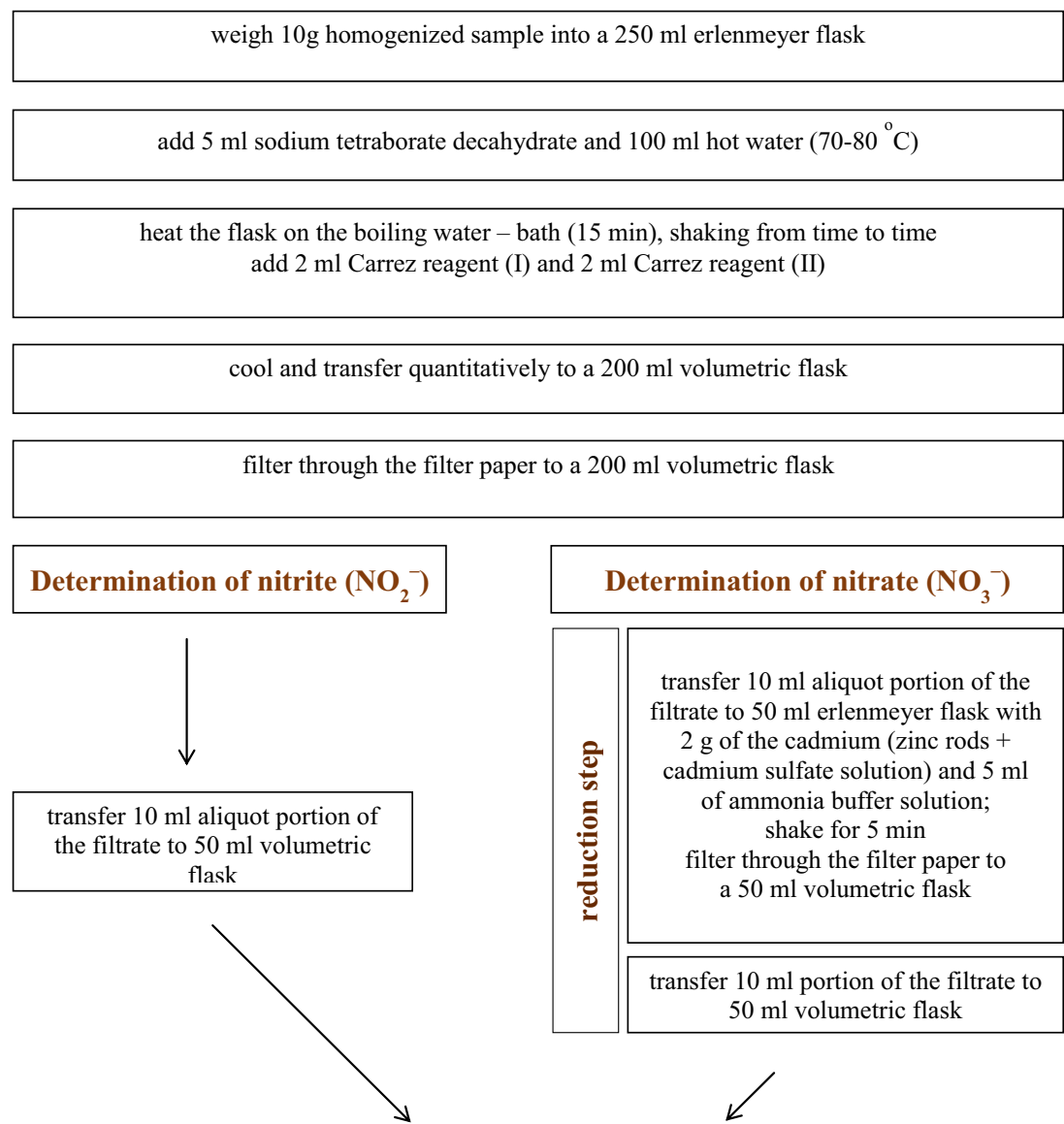

add $20 \mathrm{ml}$ water, $5 \mathrm{ml}$ Griess reagent $\mathbf{I}$ add $3 \mathrm{ml}$ hydrochloric acid leave the solution at ambient temperature, protected from light $(5 \mathrm{~min})$

add $1 \mathrm{ml}$ Griess reagent II, mix and leave the solution at ambient temperature, protected from light (3 min)

measure the absorbance of the solution using the UV-spectrometer (within $15 \mathrm{~min}$ ) 


\section{Nitrate and Nitrite Determination}

The content of nitrate $\left(\mathrm{NO}_{3}{ }^{-}\right)$ion in cucumber peel and flesh extracts was determined according to the ISO requirement (ISO 6635: 1984) using the spectrophotometric method after nitrate reduction (Fig. 1) and the Griess reaction. The nitrite $\left(\mathrm{NO}_{2}{ }^{-}\right)$ion content in extracts was determined by analyzing without the reduction step. Nitrites present in the extracts (both native and resulted from reduced nitrates) were determined by diazotizing with the Griess reagents to form of reddish purple azo dye that was measured at $538 \mathrm{~nm}$. Spectrophotometric measurements were performed by a UV/ VIS double beam spectrophotometer HALO DB-20S (Dynamica Scientific Ltd.) using $1 \mathrm{~cm}$ path length quartz cuvettes. The UV-probe software (Halo UV Detective Software) was used to control measurements and to record the spectra. The quantification of nitrates and nitrites was carried out by employing a calibration standard method. The calibration function was calculated from the regression analysis of seven standard solutions of nitrites in the range $0.05-0.60 \mathrm{mg} \mathrm{L}^{-1}$. All analyses were performed in three replicates. The nitrite concentration was expressed as $\mathrm{m} \mathrm{kg}^{-1}$ fresh mass according to the Eq. (1). The nitrate concentration ( $\mathrm{mg} \mathrm{kg}^{-1}$ fresh mass) was calculated as a difference between the total nitrite content after the reduction step (3) and the initial nitrite concentration according to the Eq. (2).

$\mathrm{NO}_{2}^{-}=m_{1} \times \frac{200 \times \mathrm{DF}}{V_{1} \times m_{0}}$

$\mathrm{NO}_{3}^{-}=1.348 \times\left(\mathrm{NO}_{x}^{-}-\mathrm{NO}_{2}^{-}\right), \quad \mathrm{NO}_{x}^{-}=m_{2} \times \frac{1000 \times D F}{V_{2} \times V_{3} \times m_{0}}$

where $\mathrm{NO}_{2}^{-}$is the initial nitrite concentration in the sample, expressed as milligrams of nitrites per kilogram (fresh mass); $\mathrm{NO}_{x}^{-}$is the total nitrite concentration after reduction (3) in the sample; $\mathrm{NO}_{3}^{-}$is the total nitrate concentration in the sample, expressed as milligrams of nitrates per kilogram (fresh mass); $m_{0}$ is the weight of the sample; $m_{1}$ is the mass $(\mu \mathrm{g})$ of initial nitrites in the filtrate portion $\left(V_{1}\right)$ read from the calibration curve; $V_{1}$ is the filtrate portion $(\mathrm{ml}) ; m_{2}$ is the mass $(\mu \mathrm{g})$ of the total nitrites in the filtrate portion $\left(V_{2}\right)$ read from the calibration curve; $V_{2}$ is the filtrate portion after reduction $(\mathrm{ml}) ; V_{3}$ is the filtrate portion before reduction $(\mathrm{ml})$; $\mathrm{DF}$ is a dilution factor $(\mathrm{DF}=1$ if no dilution was carried out); 1.348 is the conversion factor of $\mathrm{NO}_{3}^{-}$to $\mathrm{NO}_{2}^{-}$.

$\mathrm{NO}_{3}^{-}+\mathrm{Cd}+2 \mathrm{H}^{+} \rightarrow \mathrm{NO}_{2}^{-}+\mathrm{Cd}^{2+}+\mathrm{H}_{2} \mathrm{O}$

\section{Method Validation}

The method was validated in terms of a linear range, accuracy, recovery, and analytical limits including a limit of quantification (LOQ) and a limit of detection (LOD) in accordance with the International Conference on Harmonization (ICH) Guidelines (ICH 2005). Linearity was evaluated by a calculation of a seven-point linear plot with three replicates, based on a linear regression and a squared correlation coefficient $\left(R^{2}\right)$. The accuracy of the procedure was assessed by performing recovery experiments. The recovery was calculated as the difference between the pairs of results from the spiked sample and the sample without a standard addition. The nitrate and nitrite standard solutions (with the known concentrations) were used to fortify the samples. The concentration of the standard solution in the fortified samples responded to the two concentration levels of the calibration curve: the first one to the lowest level $\left(0.05 \mathrm{mg} \mathrm{L}^{-1}\right)$ and the second one to the highest level $\left(0.60 \mathrm{mg} \mathrm{L}^{-1}\right)$. The fortified samples were extracted and analyzed as described under the nitrate and nitrite determination. The measured concentrations were determined using the calibration curve, and the recovery values were calculated by the following Eq. (4):

Recovery $=\left[C_{\text {meas. }} / C_{\text {sp. }}\right] \times 100 \%$

$C_{\text {meas. }} \quad$ measured concentration

$C_{\text {sp. }} \quad$ spiked concentration

The limit of detection and the limit of quantification were calculated as follows: standard deviation of the $y$-intercept of the calibration curve/slope of the linearity, multiplied by 3.3 and 10 , respectively.

\section{Statistical Analysis}

The results were processed using statistic computer program Statgraphics Plus 3.0. for Windows ${ }^{\circledR}$. Each value represents the mean $\left(\mathrm{mg} \mathrm{kg}^{-1}\right)$ of three replicates with the corresponding standard deviation (SD). The differences between the total nitrate/nitrite contents were calculated by a one-factorial analysis of variance (ANOVA). Comparison of the mean results was done using the Tukey-Kramer test. The difference between mean values with $p$ values $<0.0001$ was considered statistically significant.

\section{Results and Discussion}

\section{Validation Results}

The method was successfully validated for the nitrite and nitrate analysis in the cucumber extracts. The validation data are summarized in Table 1. The calibration curve was linear in the studied concentration range with the square correlation coefficient $\left(R^{2}\right)$ equal to 0.9994 . The limit of detection was 0.3 and 
Table 1 Method validation data

\begin{tabular}{|c|c|c|c|c|c|c|}
\hline \multirow[t]{2}{*}{ Analyte } & \multirow[t]{2}{*}{$\mathrm{LOD}\left(\mathrm{mg} \mathrm{kg}^{-1}\right)$} & \multirow[t]{2}{*}{ LOQ (mg kg $\left.{ }^{-1}\right)$} & \multicolumn{2}{|c|}{ Recovery (\%) } & \multicolumn{2}{|c|}{$\operatorname{RSD}(\%)(n=3)$} \\
\hline & & & LL & HL & LL & $\mathrm{HL}$ \\
\hline Nitrite & 0.3 & 0.8 & 93.9 & 94.8 & 0.8 & 0.7 \\
\hline Nitrate & 1.5 & 4.6 & 81.8 & 85.7 & 1.7 & 0.9 \\
\hline
\end{tabular}

$L O D$ limit of detection, $L O Q$ limit of quantification, $R S D$ relative standard deviation, $L L$ lowest validation level, $H L$ highest validation level

$1.5 \mathrm{mg} \mathrm{kg}^{-1}$ for nitrites and nitrates, respectively. The limit of quantification was 0.8 and $4.6 \mathrm{mg} \mathrm{kg}^{-1}$ for nitrites and nitrates, respectively. The recovery of nitrites was found to be $93.9 \%$ as an average of six experiments employing two different nitrite levels. The average recovery value for nitrates was $83.8 \%$.The lower values of recovery observed for nitrates might be a result of the analyte loss during the extra step in the extraction procedure (cadmium reduction). All the obtained recovery values fulfill the recommended criteria established by the EU Commission for the official control of nitrate in foodstuff (EC 2006b). Values for a recovery of nitrates are dependent to nitrate concentration levels and are reported as $60-120 \%$ for vegetables with a nitrate content $<500 \mathrm{mg} \mathrm{kg}^{-1}$ and $90-100 \%$ for vegetables with a nitrate content $\geq 500 \mathrm{mg} \mathrm{kg}^{-1}$. The recovery and RSD (relative standard deviation) values are given in Table 1.

\section{Concentration of Nitrites and Nitrates in Cucumber Fruit Extracts}

The nitrite presence was not detected in all analyzed samples. It is comparable with various publications where the nitrite content in fresh vegetables was usually low, with average concentrations $<1 \mathrm{mg} \mathrm{kg}^{-1}$ (Vahed et al. 2015; Chung et al. 2011). In the present study, the nitrite concentrations in all tested samples were below the limit of quantification. This low concentration of nitrites is also comparable to the results obtained by Susin and co-workers (Sušin et al. 2006). Using photometer-segmented flow method, they analyzed 924 samples and reported the nitrite contents below the limit of quantification ( $\mathrm{LOQ}=0.3 \mathrm{mg} \mathrm{kg}^{-1}$ ) in 378 samples (Sušin et al. 2006).
In our study, the nitrate concentrations in all analyzed cucumber fruit extracts varied between 4.76 to $183.16 \mathrm{mg} \mathrm{kg}^{-1}$. The highest nitrate content was found in the peel of the greenhouse cucumbers $\left(183.16 \mathrm{mg} \mathrm{kg}^{-1}\right)$. The peel and the flesh of the greenhouse cucumbers had higher nitrate concentrations (133.22 \pm 37.18 and $40.11 \pm 13.09 \mathrm{mg} \mathrm{kg}^{-1}$, respectively) compared to the peel and the flesh of the cucumbers grown in open fields $\left(55.75 \pm 28.90\right.$ and $8.87 \pm 2.83 \mathrm{mg} \mathrm{kg}^{-1}$ respectively) The mean nitrate levels found in both the peel and the flesh are shown in Table 2. The obtained mean values were calculated from 15 individual results. Our results confirmed the previously described observation, about different factors such as exposure to sunlight or fertilization affecting a nitrate accumulation. Light intensity and nitrogen mineralization are widely recognized as important determinants of a nitrate level in vegetables, including cucumbers (Bottex et al. 2008). As reported by Tamme and co-workers (Tamme et al. 2010), vegetables grown in heated glasshouses have higher nitrate contents than those grown in the open air during the same season. It is also reflected in our results (Table 2). The comparison of the mean nitrate contents, using one-way ANOVA, shows that the mean nitrate contents in the cucumbers from a greenhouse are significantly higher $(p<0.0001)$ than the mean nitrate contents in cucumbers grown in open fields considering both the peel and the flesh (Figs. 2 and 3).

\section{Comparison of Nitrate Levels in the Peel and in the Flesh}

The distribution of the total nitrate contents in the extracts of the cucumber peel and flesh are presented in Fig. 4. The
Table 2 Nitrate mean contents (mg kg ${ }^{-1}$ fresh mass) in the cucumber peel and flesh extracts

\begin{tabular}{lllllll}
\hline Cucumber extract & $\begin{array}{l}\text { Number of } \\
\text { samples }^{\mathrm{a}}\end{array}$ & \multicolumn{2}{l}{ Nitrate content $\left(\mathrm{mg} \mathrm{kg}^{-1}\right)$} & \multirow{2}{*}{$\mathrm{k}^{\mathrm{b}}$} \\
\cline { 3 - 6 } & & Min & Max & Mean & SD & \\
\hline Flesh (grown in open fields) & 5 & 4.76 & 13.06 & 8.87 & 2.83 & 6.29 \\
Peel (grown in open fields) & 5 & 9.68 & 89.71 & 55.75 & 28.90 & \\
Flesh (grown in greenhouse) & 5 & 25.10 & 58.10 & 40.11 & 13.09 & 3.32 \\
Peel (grown in greenhouse) & 5 & 75.28 & 183.16 & 133.22 & 37.18 & \\
\hline
\end{tabular}

$S D$ standard deviation

${ }^{\text {a }}$ Each sample was analyzed in triplicate

${ }^{\mathrm{b}} \mathrm{k}$ mean nitrate content $\left(\mathrm{mg} \mathrm{kg}^{-1}\right)$ in peel/mean nitrate content $\left(\mathrm{mg} \mathrm{kg}^{-1}\right)$ in flesh 


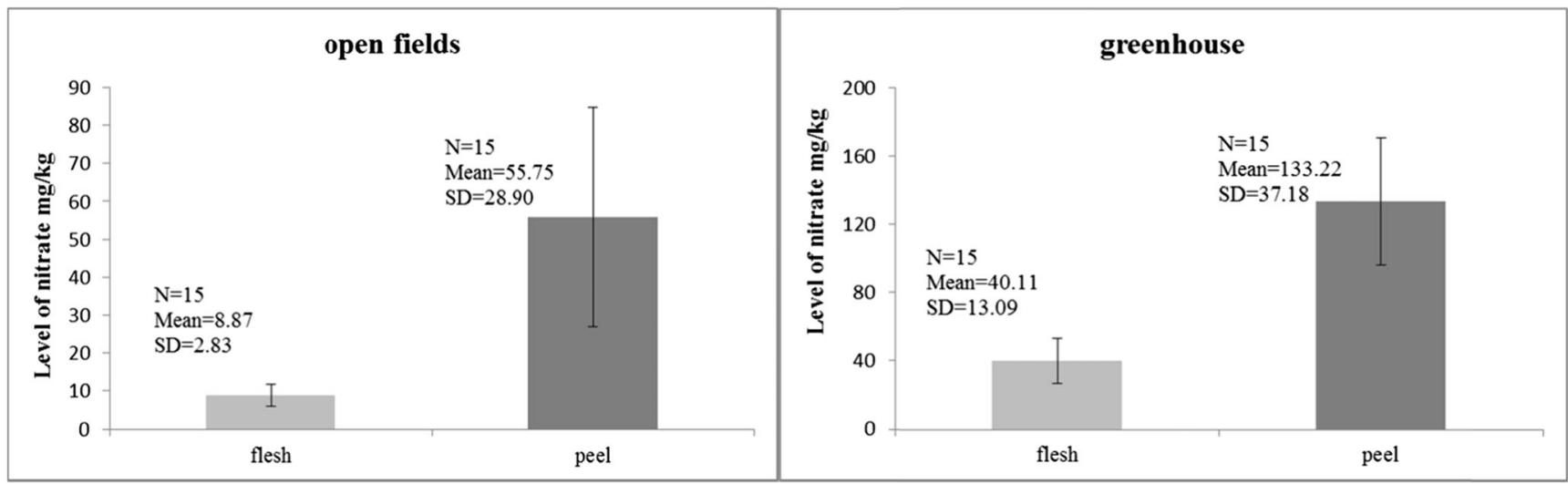

Fig. 2 Mean nitrate concentration ( $\mathrm{mg} \mathrm{kg}^{-1}$ fresh mass) in the cucumbers grown in open fields and grown in a greenhouse for flesh extracts and peel extracts

highest nitrate content found in the peel of greenhouse cucumbers was $183.16 \mathrm{mg} \mathrm{kg}^{-1}$ while in the flesh samples, the nitrate contents did not exceed $59.00 \mathrm{mg} \mathrm{kg}^{-1}$. In comparison to the greenhouse cucumbers, the content of nitrates in the cucumbers grown in open fields was much lower. The higher nitrate content in the peel was $89.71 \mathrm{mg} \mathrm{kg}^{-1}$, while in the flesh, the nitrate content was $13.06 \mathrm{mg} \mathrm{kg}^{-1}$. The comparison of the mean nitrate contents, using one-way ANOVA, clearly shows that the mean nitrate contents in the peel are significantly higher $(p<0.0001)$ from the mean nitrate contents in the flesh in both studied sorts of cucumbers (Fig. 3). The mean nitrate content in the peel was at least three times higher than the nitrate content in the flesh (Table 2). The difference between the total nitrate/nitrite contents in peel and flesh of cucumbers shown in this paper might be a starting point for further extensive studies employing larger number of samples and other reference methods.

\section{Comparison of Nitrate and Nitrite Levels in Cucumbers with Other Results from Poland and Foreign Countries}

The obtained results were compared with the values available in the literature in nine other countries and in seven other studies done in Poland. The mean and the range of concentrations for both nitrates and nitrites are summarized in Table 3. The data included in Table 3 refer to the concentration of nitrates and nitrites in whole cucumber fruit because it was not be specified otherwise. The monitoring study in Poland showed that the mean nitrate concentrations varied from $32 \mathrm{mg} \mathrm{kg}^{-1}$ (Raczuk et al. 2014) to $340 \mathrm{mg} \mathrm{kg}^{-1}$ (Czajkowska et al. 2014). According to the foreign data, the mean nitrate content in the cucumbers was very similar to the levels found in Poland and ranged between $42.7 \mathrm{mg} \mathrm{kg}^{-1}$, reported in Iran (Rezaei et al. 2014) to $344 \mathrm{mg} \mathrm{kg}^{-1}$ in Belgium (Temme et al. 2011). The maximum nitrate content of $1800 \mathrm{mg} \mathrm{kg}^{-1}$ was found in France (Menard et al. 2008). The minimum nitrate content of $1 \mathrm{mg} \mathrm{kg}^{-1}$ was found in Korea during the summer period (Chung et al. 2003). The nitrite contents found in cucumbers were generally low and in most cases did not exceed $1 \mathrm{mg} \mathrm{kg}^{-1}$. The exceptional results were discussed by Razei (Rezaei et al. 2014) with the mean content of $9.03 \mathrm{mg} \mathrm{kg}^{-1}$. Considering the present study, the mean nitrate content found in the cucumbers' flesh was $24.5 \mathrm{mg} \mathrm{kg}^{-1}$, and in most cases it was lower than the nitrate concentrations in the whole cucumber fruit from Poland and other countries. The mean nitrate content in

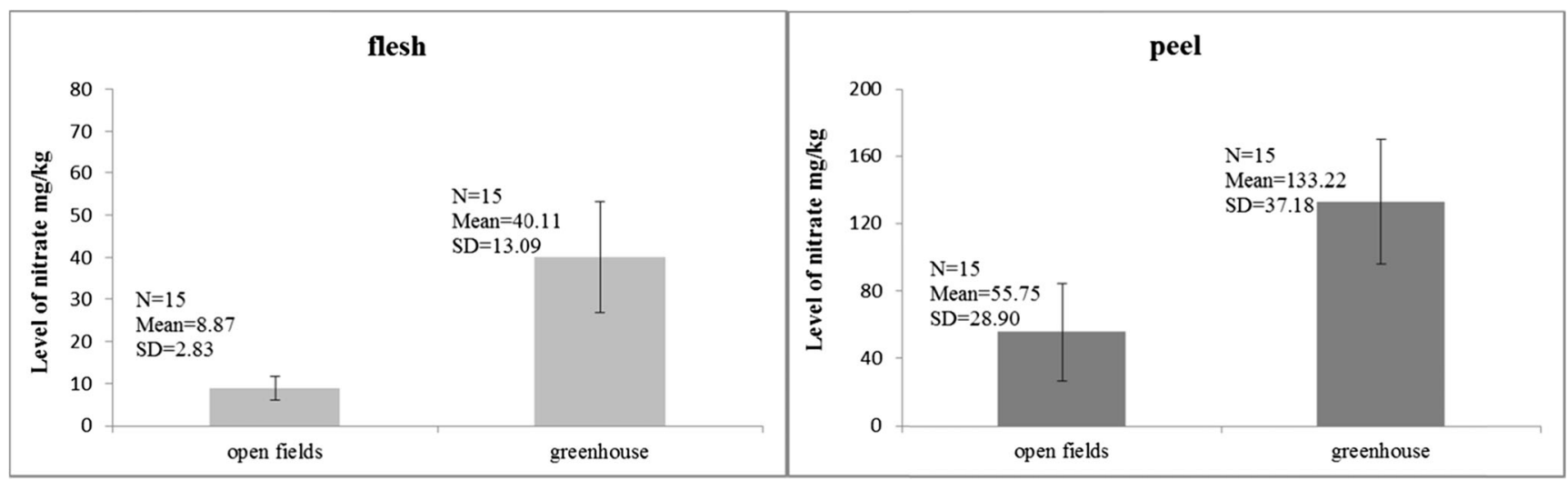

Fig. 3 Mean nitrate concentration ( $\mathrm{mg} \mathrm{kg}^{-1}$ fresh mass) in flesh and peel of cucumbers grown in open fields and grown in greenhouses 
Fig. 4 Distribution of total nitrate contents ( $\mathrm{mg} \mathrm{kg}^{-1}$ fresh weight) in the cucumber peel and flesh

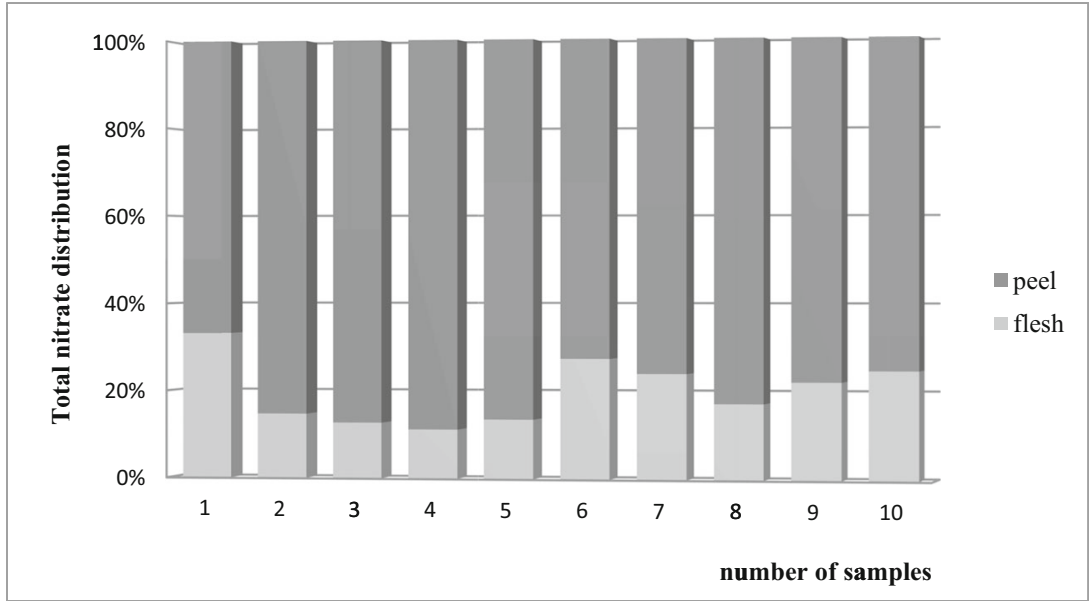

the cucumber peel was $94.5 \mathrm{mg} \mathrm{kg}^{-1}$ and it is comparable to the other studies. Consequently, it is the cucumber peel that contains the majority of nitrates in an average cucumber fruit, as it may be concluded from the data collected in Table 3.

Table 3 Comparison of mean nitrate and nitrite contents of cucumbers ( $\mathrm{m} \mathrm{kg} \mathrm{k}^{-1}$ fresh mass) in different countries

\begin{tabular}{|c|c|c|c|c|c|}
\hline & No. of samples & $\begin{array}{l}\text { Nitrate }\left(\mathrm{mg} \mathrm{kg}^{-1}\right) \\
\text { mean/range }\end{array}$ & $\begin{array}{l}\text { Nitrite }\left(\mathrm{mg} \mathrm{kg}^{-1}\right) \\
\text { mean/range }\end{array}$ & Analytical method & References \\
\hline \multirow[t]{2}{*}{ China } & $\begin{array}{l}- \\
-\end{array}$ & $\begin{array}{l}130 / 57-260.0 \\
99 / 28-140\end{array}$ & $<0.8-0.9$ & IC & Chung et al. 2011 \\
\hline & 23 & $170 / 17.4-500$ & $0.2 / 0.03-1.11$ & IC & Zhong et al. 2002 \\
\hline Korea & $\begin{array}{l}15 \\
25\end{array}$ & $\begin{array}{l}267 / 83-580 \\
180 / 1-649\end{array}$ & $\begin{array}{l}0.3 / \mathrm{ND}-1.4 \\
0.2 / \mathrm{ND}-1.5\end{array}$ & IC & Chung et al. 2003 \\
\hline USA & - & $190 / 17-570$ & - & - & Keeton et al. 2012 \\
\hline \multirow[t]{2}{*}{ Estonia } & & $160 /<30-1236$ & - & Potentiometry & Tamme et al. 2006 \\
\hline & 12 & $335 / 89-740$ & - & HPLC & Tamme et al. 2010 \\
\hline Slovenia & 30 & $93 / 4-245$ & $0.2 / 0.16-0.4$ & Photometry & Sušin et al. 2006 \\
\hline Belgium & - & $344 /-$ & - & HPLC & Temme et al. 2011 \\
\hline \multirow[t]{2}{*}{ Iran } & 29 & $42.7 / 12.32-88.6$ & $9.03 / 2.8-18.5$ & Spectrophotometry & Rezaei et al. 2014 \\
\hline & 41 & $* 87.7 / 44.6-103$ & $* 0.57 / 0.33-0.81$ & Spectrophotometry & Bahadoran et al. 2016 \\
\hline Italy & - & $79 /-$ & $0.21 /-$ & IC & Santamaria et al. 1999 \\
\hline France & 33 & $-/ 191.6-1800$ & $-/ 0.00-2.00$ & IC & Menard et al. 2008 \\
\hline \multirow[t]{8}{*}{ Poland } & 6 & $32 / 24-40$ & $0.5 / 0.4-0.8$ & Spectrophotometry & Raczuk et al. 2014 \\
\hline & - & $340 /-$ & - & IC & Czajkowska et al. 2014 \\
\hline & $\begin{array}{l}20 \\
20\end{array}$ & $\begin{array}{l}98.4 / 41.2-312.3 \\
105.9 / 44.7-354.7\end{array}$ & $\begin{array}{l}0.6 /<0.5-1.3 \\
0.6 /<0.5-1.2\end{array}$ & Spectrophotometry & Gajewska et al. 2009 \\
\hline & 24 & $255.5 / 28.6-1040.2$ & $0.28 / \mathrm{ND}-2.5$ & Spectrophotometry & Szymczak and Prescha 1999 \\
\hline & $\begin{array}{l}20 \\
3\end{array}$ & $\begin{array}{l}56.56 / 14.8-149.6 \\
72.34 / 14.2-198\end{array}$ & $\begin{array}{l}0.51 / 0.33-1.54 \\
1.01 / 0.82-1.18\end{array}$ & Spectrophotometry & Murawa et al. 2008 \\
\hline & 28 & $115 / 21.9-446.8$ & $0.25 / 0.0-0.52$ & Spectrophotometry & Markowska et al. 1995 \\
\hline & - & $313.1 /-$ & - & $\mathrm{GC}$ & Tietze et al. 2007 \\
\hline & $\begin{array}{l}10 \\
10\end{array}$ & $\begin{array}{l}{ }^{\mathrm{a}} 24.5 / 4.8-58.1 \\
\mathrm{~b}_{9} 94.5 / 9.7-183.2\end{array}$ & - & Spectrophotometry & current study \\
\hline
\end{tabular}

$I C$ ion chromatography, HPLC high pressure liquid chromatography, $G C$ gas chromatography

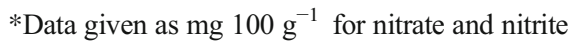

${ }^{\text {a }}$ Data of the current study for flesh of cucumber

${ }^{b}$ Data of the current study for peel of cucumber, graphite color represents winter season 


\section{Conclusions}

In the present investigation, the mean contents of nitrates and nitrites in cucumbers were determined by means of a spectrophotometric technique, with a particular attention to the difference between the peel and the flesh. All the fresh cucumbers analyzed in this study did not present exceptionally high values in comparison to the reviewed data from Poland and nine other countries, neither in peel nor in flesh. The nitrate levels in the cucumber peel extracts were similar to or even lower than the values given for the whole cucumbers in other studies. The average nitrate content in the cucumber flesh was below any other value published in the literature. However, it should be emphasized that the cucumber peel usually contains about three times more nitrates than the flesh, regardless of the manner of cultivation (greenhouse or open field).

Acknowledgements The authors thank Dr. Ilona Sadok from the Centre for Interdisciplinary Research for critical review of the manuscript.

Funding information This work was supported by the European Union from European Regional Development Fund under the Operational Programme Development of Eastern Poland 2007-2013 (agreement POPW.01.03.00-06-003/09-00).

\section{Compliance with Ethical Standards}

Conflict of Interest Author A. Stachniuk declares that she has no conflict of interest. Author A. Szmagara declares that she has no conflict of interest. Author E.A. Stefaniak declares that she has no conflict of interest.

Ethical Approval This article does not contain any studies with human participants or animals performed by any of the authors.

\section{Informed Consent Not applicable.}

Open Access This article is distributed under the terms of the Creative Commons Attribution 4.0 International License (http:// creativecommons.org/licenses/by/4.0/), which permits unrestricted use, distribution, and reproduction in any medium, provided you give appropriate credit to the original author(s) and the source, provide a link to the Creative Commons license, and indicate if changes were made.

\section{References}

Bahadoran Z, Mirmiran P, Jeddi S, Azizi F, Ghasemi A, Hadaegh F (2016) Nitrate and nitrite content of vegetables, fruits, grains, legumes, dairy products, meats and processed meats. J Food Compos Anal 51:93-105

Bottex B, Dorne JLCM, Carlander D, Benford D, Przyrembel H, Heppner C, Kleiner J, Cockburn A (2008) Risk — benefit health assessment of food-food fortification and nitrate in vegetables. Trends Food Sci Technol 19:113-119

Chung SY, Kim JS, Kim M, Hong MK, Lee JO, Kim CM (2003) Survey of nitrate and nitrite contents of vegetables grown in Korea. Food Addit Contam 20(7):621-628
Chung SWC, Tran JCH, Tong KSK, Chen MYY, Xiao Y, Ho YY, Chan CHY (2011) Nitrate and nitrite levels in commonly consumed vegetables in Hong Kong. Food Addit Contam B 4:34-41

Cortesi ML, Vollano L, Peruzy MF, Marrone R, Mercogliano R (2015) Determination of nitrate and nitrite levels in infant foods marketed in Southern Italy. CyTA J Food 13(4):629-634

Costagliola A, Roperto F, Benedetto D, Anastasio A, Marrone R, Perillo A, Russo V, Papparella S, Paciello O (2014) Outbreak of fatal nitrate toxicosis associated with consumption of fennels (Foeniculum vulgare) in cattle farmed in Campania region (southern Italy). Environ Sci Pollut Res 21(9):6252-6257

Czajkowska A, Gajewska M, Bartodziejska B (2014) Adapting IC-DAD method with sample preparation as modified by authors to determine content of nitrates (III) and nitrates (V) in food products. Żywność. Nauka. Technologia. Jakość 6:92-101 [in Polish]

EC (2006a) Commission Regulation EC No 1882/2006 of 19 December 2006 setting maximum levels for certain contaminants in foodstuffs. Off J Eur Union 364:5-24

EC (2006b) Laying down methods of sampling and analysis for the official control of the levels of nitrate in certain foodstuff (Commission Regulation EC No 1882/2006). Off J Eur Union 364:25-31

Eifediyi EK, Remison SU (2010) Growth and yield of cucumber (Cucumis sativus L.) as influenced by farmyard manure and inorganic fertilizer. J Plant Breed Crop Sci 2(7):216-220

Ekart K, Hmelak Gorenjak A, Madorran E, Lapajne S, Langerholc T (2013) Study on the influence of food processing on nitrate levels in vegetables. EFSA Support Publ 2013:EN-514

Gajewska M, Czajkowska A, Bartodziejska B (2009) The content of nitrates (III) and (V) in selected vegetables on detail sale in Lodz region. Ochrona Środowiska i Zasobów Naturalnych 40:388-395 [in Polish]

Gorenjak H, Cencič A (2013) Nitrate in vegetables and their impact on human health. A review. Acta Aliment 42(2):158-172

Gruda N (2005) Impact of environmental factors on product quality of greenhouse vegetables for fresh consumption. Crit Rev Plant Sci 24: 227-247

Guler Z, Karaca F, Yetisir H (2013) Volatile compounds in the peel and flesh of cucumber (Cucumis sativus L.) grafted onto bottle gourd (Lagenaria siceraria) rootstocks. J Hortic Sci Biotechnol 88(2):123-128

ICH (2005) Harmonised tripartite guideline, validation of analytical procedures: text and methodology Q2(R1)

ISO International Organization for Standardization. ISO 6635 (1984) Fruits, vegetables and derived products - Determination of nitrite and nitrate content

Keeton JT, Osburn WN, Hardin MD, Bryan NS, Longnecker T (2012) A national survey of the nitrite/nitrate concentrations in cured meat products and nonmeat foods available at retail. J Agric Food Chem 60:3981-3990

Kmecl V, Knap T, Znidarcic D (2017) Evaluation of the nitrate and nitrite content vegetables commonly grown in Slovenia. Ital J Agron 12(2): $79-84$

Korzeniewska A, Gałecka T, Guzowska E, Niemirowicz-Szczyt K (2016) A new type of semi-bush habit processing cucumber (Cucumis sativus) for simplified fruit harvest. In: Kozik EU, Paris HS (eds) Proceedings of Cucurbitaceae 2016. Sigma, Warsaw, pp 11-15

Kozik E (2016) History of cucumber breeding in Poland. In: Kozik EU, Paris HS (eds) Proceedings of Cucurbitaceae 2016. Sigma, Warsaw, pp 11-15

Leili M, Pirmoghani A, Samadi AT, Shokoohi R, Roshanaei G, Poormohammadi A (2016) Determination of pesticides residues in cucumbers grown in greenhouse and the effect of some procedures on their Resi-dues. Iran J Public Health 45(11):1481-1490

Mansfeld BN, Grumet R (2016) Metabolomic plasticity of cucumber fruit peel - effects of developmental stage and market class. In: Kozik EU, Paris HS (eds) Proceedings of Cucurbitaceae 2016. Sigma, Warsaw, pp 11-15 
Mansour SA, Belal MH, Abou-Arab AA, Gad MF (2009) Monitoring of pesticides and heavy metals in cucumber fruits produced from different farming systems. Chemosphere 75:601-609

Markowska A, Kotkowska A, Furmanek W, Gackowska L, Siwek B, Kacprzak -Strzałkowska E, Blonska A (1995) Estimation of contents of nitrate and nitrite in vegetables from the province of Lodz. Rocz Państw Zakł Hig XLVI(4):341-346 [in Polish]

Menard C, Heraud F, Volatier JL, Leblanc JC (2008) Assessment of dietary exposure of nitrate and nitrite in France. Food Addit Contam A 25:971-988

Murawa D, Banaszkiewicz T, Majewska E, Błaszczuk B, Sulima J (2008) Nitrate and nitrite content in selected vegetables and potatoes commercially available in Olsztyn. Bromatol Chem Toksykol XLI(1): 67-71 [in Polish]

Opinion SCF (2008) Opinion of the scientific panel on contaminants in the food chain on a request from the European Commission to perform a scientific risk assessment on nitrate in vegetables. EFSA J 689:1-79

Raczuk J, Wadas W, Glozak K (2014) Nitrates and nitrites in selected vegetables purchased at supermarkets in Siedlce, Poland. Rocz Państw Zakł Hig 65:15-20 [in Polish]

Razgallah N, Chikh-Rouhou H, Boughattas I, Mhamadi M (2016) Nitrate contents in some vegetables in Tunesia. Arch Argonomy Soil Sci 62(4):473-483

Rebelo JS, Almeida MD, Vales L, Almeids CMM (2015) Precence of nitrates in baby foods marketed in Portugal. Cogent Food Agric 1:1-14

Rezaei M, Fani A, Moini AL, Mirzajani P, Malekirad AA, Rafiei M (2014) Determining nitrate and nitrite content in beverages, fruits, vegetables, and stews marketed in Arak, Iran. Int Sch Res Not 2014:1-5

Sahar N, Mubarik A, Parveen Z, Ilyas A, Abbas Bhutto A (2009) Screening of mycotoxins in wheat, fruits and vegetables grown in Sindh, Pakistan. Pak J Bot 41(1):337-341

Santamaria P (2006) Review. Nitrate in vegetables: toxicity, content, intake and EC regulation. J Food Agric 86:10-17

Santamaria P, Elia A, Serio F, Todaro E (1999) A survey of nitrate and oxalate content in fresh vegetables. J Food Agric 79:1882-1888
Shariati-Rad M, Irandoust M, Niazi F (2015) A sensitive spectrofluorimetric method for determination of nitrite agricultural samples. Food Anal Method 8:1691-1698

Sušin J, Kmecl V, Gregorčič A (2006) A survey of nitrate and nitrite content of fruit and vegetables grown in Slovenia during 19962002. Food Addit Contam 23:385-390

Szymczak J, Prescha A (1999) Content of nitrates and nitrites in market vegetables in Wrocław in the years 1996-1997. Rocz Państw Zakł Hig 50:17-23 [in Polish]

Tamme T, Reinik MM, Roasto M, Juhkam K, Tenno T, Kiis A (2006) Nitrates and nitrites in vegetables and vegetable-based products and their intakes by the Estonian population. Food Addit Contam 23: 355-361

Tamme T, Reinik M, Roasto M, Meremäe K, Kiis A (2010) Nitrate in leafy vegetables, culinary herbs, and cucumber grown under cover in Estonia: content and intake. Food Addit Contam B 3:108-113

Temme EHM, Vandevijvere S, Vinkx C, Huybrechts I, Goeyens L, Oyen HV (2011) Average daily nitrate and nitrite intake in the Belgian population older than 15 years. Food Addit Contam A 28:11931204

Tietze M, Burghardt A, Bragiel P, Mac J (2007) Content of nitrosamines in foodstuff. Ann Univ Mariae Curie-Sk łodowska Sect EE XXV: 71-77 [in Polish]

Vahed S, Mosaha L, Mirmohammadi M, Lakzadeh L (2015) Effect of some processing methods on nitrate changes in different vegetables. Food Measures 9:241-247

Vasco ER, Alvito PC (2011) Occurrence and infant exposure assessment of nitrates in baby foods marketed in the region of Lisbon, Portugal. Food Addit Contam B. 4(3):218-225

Wang Q, Huang H, Ning B, Li M, He L (2016) A highly sensitive and selective spectrofluorimetric method for the determination of nitrite in food products. Food Anal Methods 9:1293-1300

Zhong W, Hu C, Wang M (2002) Nitrate and nitrite in vegetables from north China: content and intake. Food Addit Contam 19(12):11251129 